\title{
Impact of Self Service Technology Quality on Customer Satisfaction: A Case of Retail Banks in Western Province in Sri Lanka
}

\author{
H.M.R.S.S.Gunawardana, ${ }^{a *}$ Kulathunga D., ${ }^{\mathrm{b}}$ and W.L.M.V.Perera, ${ }^{\mathrm{a}}$ \\ ${ }^{a}$ Departmentof Marketing Management, Faculty of Commerce and Management, University of Kelaniya, Sri Lanka

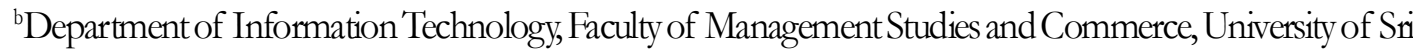

Jayewardenepura,SiiLanka

\begin{abstract}
Rapid technological advancement in the banking environment drives Sri Lankan banks to adopt self-service technologies to deliver services via SMS banking, Internet banking and telephone banking facilities, Automated Teller Machines (ATM) etc. This study explored the perceived quality of the selfservice technology of these services and its effect on customer satisfaction. The literature survey and in depth interviews helped to formulate quality dimensions: security, efficiency, eases of use, reliability and convenience and those dimensions were assessed through a questionnaire. This study surveyed 215 customers from branches of six dominating commercial banks located in Western Province of Sri Lanka. Data were subjected to Principal Component Analysis and retained factors were regressed using multiple regressions to assess the impact of quality dimensions on customer satisfaction. The results revealed that reliability and convenience have positive impacts on customer satisfaction but efficiency has a negative effect.
\end{abstract}

Abstrak: Kemajuan teknologiyang cepat dalam lingkungan perbankan mendorong bank-bank Sri Lanka untuk mengadopsi teknologi self-service dalam memberikan layanan melalui SMS banking, internet banking dan fasilitas phone banking, Automated Teller Machines (ATM) dan lain sebagainya. Penelitian ini mengeksplorasi kualitas yang dirasakan dari layanan teknologi ini dan efeknya terbadap kepuasan pelanggan. Survei literatur dan wawancara mendalam membantu untuk merumuskan dimensi kualitas: keamanan, efisiensi, kenyamanan penggunaan, keandalan dan kenyamanan dan dimensi-dimensi tersebut dinilai melalui kuesioner. Penelitian ini mensurvei 215 pelanggan dari enam cabang bank komersial yang mendominasi dan terletak di Provinsi Sri Lanka Barat. Data dijadikan sebagai komponen Sasaran Analisis Utama dan beberapa faktor yang tertahan di tarik ke arah yang berlawanan menggunakan regresi berlipat untuk memperoleh akses terhadap pengaruh dimensi-dimensi kualitas terhadap kepuasan pelanggan. Hasil penelitian menunjukkan babwa keandalan dan kenyamanan memiliki dampak positif pada kepuasan pelanggan sedangkan efisiensi memiliki dampak negatif.

Keywords: commercial banks; SST quality; satisfaction; Sri Lanka

JEL classification: M00, M15, M31

* Corresponding author's e-mail: sampath@kln.ac.lk or hmsameera@gmail.com 


\section{Introduction}

Rapid advancement of technologies has allowed many service oriented organizations to enter into a technology mediated self-service environment and it is extensively exhibited in the retail banking environment. Service organizations, including retail banks, deliberately adopt self-service technologies while encouraging their customers to adopt them too (Dabholkar and Bagozzi 2002; Zhu et al. 2013), in which customers produce and consume services by themselves without direct employee assistance (Meuter et al. 2005). Retail banks employ numerous types of selfservice channels to reach their customers including ATM, Automated Telephone Banking, Web Banking, SMS Banking, Kiosks etc. Particularly, banks deploy a number of different channels to deliver their services to customers and therefore these service channels play an important role in consumer interactions with retail banks. Motivated by efficiency gains, flexibility and productivity and improved corporate performances (Dabholkar 1996), service organizations, including retail banks, are driven to readily apply different types of self service technologies (SST) (Lee et al. 2009) and therefore, it is necessary to understand the customer evaluation of these multiple service channels in order to improve the organizational status, especially in banks and customer satisfaction in a dynamic competitive environment (Orel and Kara 2014).

Nevertheless, existing research on selfservice technology quality evaluation is limited to internet based services (Lin and Hsieh 2011) or e-services (Orel and Kara 2014) while ignoring the other self- service channels applied by service organizations (Shamdasani et al. 2008). Therefore, more exploration of customer perception of self- service technologies is needed (Schumann et al. 2012). Further, instruments for systematically measuring the quality of SST as a whole remain underdeveloped (Verhoef et al. 2009) or inconsistencies have been found in their conceptualization (Lee et al. 2011) and even the applicability of the models to test the perceived service quality that have been developed vary across the SST diffusion phases and within different markets (Lin and Hsieh 2011). Additionally, given the importance of customer satisfaction in service setting, a significant number of studies have been devoted to assessing the relationship between service quality and satisfaction. Yet in literature, the impact of self-service on customer satisfaction is unresolved due to the conflicting results on the direction of impact (Buell et al. 2010) and even these relationships are tested by selecting one service channel at a time. Consequently, there is a strong need to assess the service quality dimensions of self-service technology (Shamdasani et al. 2008) as a whole in the banking context along with their effect on customer satisfaction. In addition to that, a contextual understanding of perceived SST quality of banking environment in a growing economic environment is needed.

Thus, the objectives of the current study are twofold. First, it attempts to examine service quality dimensions to measure the SST quality of retail banks by using five attributes including ease of use, reliability, efficiency, convenience and security. Particularly, high mobile phone penetration along with the increasing internet usage in Sri Lanka has forced many retail banks to offer their services through new service channels, i.e. through self-service technologies, in order to be more competitive. This allows Sri Lankan banking customers to access their bank accounts via these technologies and to conduct 
a range of transactions including the payment of utility bills, transfer funds, etc. instead of physically visiting their banks. This has permitted banks to reduce their costs drastically while converting growing tech-oriented Sri Lankan banking customers to self-service customers. Accordingly, fast implementation of ATM, Automated Telephone Banking, Web Banking, SMS Banking, Kiosks can be seen in the retail banking environment in Sri Lanka. In such a context, it is important to recognize the quality of self-service technologies introduced by Sri Lankan banks.

Second, this study attempts to investigate the impact of these perceived quality attributes on customer satisfaction. Similarly, it is essential to identify whether Sri Lankan customers are satisfied with the quality of the existing self-service technologies of Sri Lankan banks. Hence, researchers have investigated the impact of perceived quality of SST on customer satisfaction of the retail banking environment in Sri Lanka under this research.

In order to achieve the above objectives, the rest of the paper is organized as follows. Initially, the authors present the overview of the existing literature on SST quality and satisfaction that is valuable for the present study. This is followed by a hypothesis related to service quality and satisfaction. The next section describes the sample selection and measures used in this study. Subsequently, the results of the analyses are presented and discussed. Finally, the authors present the conclusion, implications, and future research directions.

\section{Literature Review}

\section{Self-Service and Quality Attributes}

Traditionally, consumers directly interact with service organizations and service encounters take place between the front line service employees and the consumers (Bitner 1990); this traditional interpersonal focus of service encounters is heavily replaced by technologies (Bitner et al. 2000) and presently consumers encounter these new self-service technology facilities (Beatson et al. 2007; Meuter et al. 2000). These new service delivery approaches play a more important role in the service environment (Beatson et al. 2007) and they can be defined as technological interfaces that enable customers to produce a service independent of direct involvement of the service employees or minimum participation of service employees (Orel and Kara 2014; Meuter et al. 2000). Usage of SST can be seen in a range of services including traditional high contact services and low contact services (Curran et al. 2003) and range from Automated Teller Machines (ATM) at banks, self-accessed airline services or hotel facilities, self-scanning supermarket checkouts, web interfaces in banks, Kiosks in airlines, and pay at pumps in gas stations etc.

Self-service technologies are popular among retailers including banks though it is a resource intensive investment. Yet, as per the researchers, it provides a payoff for the organization by giving range of advantages (Beatson et al. 2007) including productivity 
gains though a reduced number of employees and longer opening hours (Curran et al. 2003; Dabholkar 1996), lowering labor costs (Lin and Hsieh 2011), speed of service delivery (Zhu et al. 2013) and further it has the advantage of limiting the two difficulties of traditional service delivery namely heterogeneity and perishability (Curran et al. 2003). These benefits drive service organizations to utilize a range of SST encounters for its customers and it has become the major trend in the present environment (Lin and Hsieh 2011). Accordingly, banks have adopted these technologies heavily to deliver the services through new channels, i.e. Automated Teller Machines (ATM), Web based banking, Kiosks, Short Message System Banking, App based banking etc. These service delivery mechanisms in banking environment are also known as "off-site" (Lee et al. 2011) transaction options for customers.

Apparently, retail banking customers tend to evaluate the quality of these channels in the SST encounter environment and therefore the success of these service deliveries largely rests on the quality of the ser-

\section{Table 1. Previous Findings on SST Quality Attributes}

\section{Service Quality Attributes}

Convenience, queue management, personalizing,

responsiveness, security, commitment, Trust,

(M. A. Al-Hawari 2011)

Customer Delight

Ease of use, usefulness, Cost saved, self-control

(Ho and Ko 2008)

Functionality, enjoyment, security/privacy, Assurance,

(Lin and Hsieh 2011)

Design, Convenience, Customization

Convenience, Ease of use, Control, Enjoyment

(Lee et al. 2011)

Efficiency, ease of use, performance, perceived control,

(Yen 2005)

convenience

Functionality, enjoyment, assurance, design, convenience

(Orel and Kara 2014)

Speed of service, ease of use, reliability, enjoyment,

(Shamdasani et al. 2008)

control

Availability, perceived risk, ease to use, compatibility of devices, entertainment

(Özer et al. 2013)

Fulfillment, security, reliability, efficiency, responsiveness, web site attributes, privacy

(George and Kumar 2014)

Web design, reliability, security, customer service,

(H. H. Chang et al. 2009)

customer perceived value

Reliability, responsiveness, competence, ease of use,

(Yang et al. 2004)

product portfolio, security 
vice. Nonetheless, SST quality remains underdeveloped (Lin and Hsieh 2011) due to usage of channel specific measurement of service quality in the internet/web environment (Lee et al. 2011; Lin and Hsieh 2011; Parasuraman et al. 2005). Thus, it reduces the ability to generalize these scales to measure the range of SST quality (Lin and Hsieh 2011). Hence, this requires common definition for overall self-service technology quality and the overall excellence of the service delivered through internet, ATM, telephone banking, Kiosks, SMS etc (Al-Hawari et al. 2003). Academic researchers have mentioned the usage of criteria/attributes to assess the quality of self-services (Dabholkar 1996; Lin and Hsieh 2011; Shamdasani et al. 2008). As a result, perceived attributes pertaining to self-service technologies have been largely utilized to assess the quality of self-service technologies (Al-Hawari et al. 2005; Dabholkar 1996; Meuter et al. 2000; Shamdasani et al. 2008).

Accordingly, an extensive literature review was undertaken to propose five attributes to measure the service quality of the SST environment of banks. Table 1 shows the various quality dimensions so far identified in the literature to explain the perceived service quality of SST. The quality dimensions for this study were identified by evaluating the existing studies in similar context and were finalized by obtaining the insights from academic experts, managers and customers (Figure 1).

Firstly, time conscious consumers see self-service technologies as a time efficient mechanism to obtain services (Bateson 1985) from the service organizations. Accordingly, the efficiency attribute is the reduction of time and effort that is required to complete the tasks (Johnson et al. 2008) and the cost associated with transactions in the tech-en- abled service environment. Further, Yen (2005) stated efficiency as the ability of SST to solve users problems better than other options while saving time. Accordingly, speed of service or time taken to perform the transaction plays a vital role in deciding the quality of SST (Al-Hawari 2011). As per Yen (2005) citing (Ledingham 1984) speed as being considered an important factor among consumers whenever conducting IT based banking activities. As per Meuter et al. (2000), time savings offered by SST play a bigger role in consumers adopting SST and therefore they significantly influence consumers in evaluating the quality of service in the selfservice environment (Shamdasani et al. 2008). Additionally, possible customer cost savings (i.e. expend fewer resources on travelling and conducting transactions) associated with SST play a considerable role in evaluating SST by the customers.

Secondly, Davis (1986) has mentioned the importance of perceived ease of use of a system for it to be accepted by the users and further he defined it as "degree to which a person believes that using a particular system will be free of effort." Consumers consider the effort involved in learning and using new systems (Oghazi et al. 2012) and they tend to avoid systems which require extra effort of mentally and physically (Bateson 1985; and Venkatesh 2000). Accordingly, effort and complexity of a system are found to be related concepts and encompass the concept of ease of use (Davis et al. 1989) and therefore, ease of use was found be the one quality dimension of assessing self-service technology (Venkatesh 2000; andVenkatesh et al. 2002). User-friendly interfaces drive consumers to evaluate SST positively (Lee et al. 2011) and indication of proper instructions in the SST environment reduces personal effort and risk from learning new fea- 
tures by spending time and the possibility of making errors (Shamdasani et al. 2008). Equally, it focuses on the interactivity aspects of the interface of SST (Collier and Kimes 2012). Thus, customers feeling comfortable using SST improves the perception of SST (Kim and Stoel 2004; and Lin and Hsieh 2011).

The third attribute is reliability and it encompasses the accuracy of the service received over the SST (Shamdasani et al. 2008) and Yen (2005) termed it as performance. Researchers have found out about the importance of reliability in service encountering environments (Davis et al. 1989; and Parasuraman et al. 1988) and especially in the electronic banking environment (Lee and Lin 2005). Tasks performed in service encounters should be free from errors. Specifically, new service delivery mechanisms such as SST raise the issue of breakdowns causing customers to lose faith in them. Thus correct functioning and accurate service delivery are important aspects of the service quality SST environment (Lin and Hsieh 2011). Accurate and error free performance of SST (Lin and Hsieh 2011 citing Zeithaml et al. 2002) leads to favorable evaluation of service quality of SST and this was also noted by Collier and Kimes (2012).

The fourth attribute is convenience and it refers to the availability of SST to customers 'when and where they need it' (Meuter et al. 2000). It is the perceived ability of access to SST for customers at the time and location convenient for them (Yen 2005). In a selfservice environment customers are in greater control of dictating the time and location of service consumption and therefore it overcomes the problem of inconvenience of the full service environment (Collier and Kimes 2012). Nevertheless, the ability of the customers to access intended service from any devices given by the organizations, irrespective of the location and time, is considered as a key indicator of SST quality (Lin and Hsieh 2011) since it gives an effective transaction experience for the customers (Collier and Kimes 2012). Accordingly, Collier and Sherrell (2010) noted the importance of the convenience factor in evaluating the SST and Ding et al. (2011) noted the criteria of convenience when evaluating service quality of SST.

The final and the fifth attribute is security and it refers to freedom from danger, risks or doubts that customer will feel (Li and Suomi 2009) while interacting with self-service technologies. As per the study by Parasuraman et al. (2005), security and privacy are most important factors in evaluating SST. Similarly, customers tend to assess the SST as to what extent it reduces their stress (Bobbitt and Dabholkar 2001) and anxieties due to lack of control exerted over the information exchange through the SST. Therefore, SST should be free of performance ambiguities (Parasuraman 2000) in order for it to be perceived as a quality service environment. Perceived risk and uncertainty have a negative impact on the attitude of the consumers and evaluation of SSTs (Pan and Zinkhan 2006), therefore customers tend to evaluate the security of the system whenever they consume the service rendered over SST. In other words, there is an inclination on the part of consumer to evaluate the probability of improper usage of information exchange over SST (Li and Suomi 2009). So, this plays a vital role in evaluating the quality of SST. 


\section{Satisfaction and Quality Satisfaction}

Academic researchers have proclaimed the importance of customer satisfaction to assess the future performance of organizations when compared with financial and accounting based measures (Miguel-Dávila et al. 2010). It is recognized as a fundamental marketing concept (Fournier and Mick 1999) driving managers to set it as one of the major objectives of marketing organizations. Hence, this has been studied heavily in the domain of marketing (Fornell 1992; and Oliver 1980). Accordingly, literature has two view points on satisfaction: the transaction-specific construct which results from immediate post purchase judgment (Oliver 1993) and the cumulative-specific construct which resulted from customers' overall experience to date with a product or service (Anderson et al. 1994). However, this study rests on cumulative customer satisfaction and accordingly it is customers' overall judgment towards service experience within the SST service environment provided by service organization. Nevertheless, service quality has been recognized as an important antecedent that decides customer satisfaction and according to Cheng et al. (2013) it has become an effective strategy to evaluate the perception of satisfaction regarding the service quality. Additionally, service quality is found to be the most influential antecedent for customer satisfaction in the service environment (Andreassen 2000; Baker and Crompton 2000) but also high customer satisfaction due to the high service quality (Darsono and Junaedi 2006). Contrary to that, there is literature that also indicates conflicting results of the direction of impact of service quality on customer satisfaction (Buell et al. 2010).

Nevertheless, when it comes to the SST environment, Dabholkar (1996) proposed
SST an attribute based model to explain the quality satisfaction in the SST service environment (Figure 1). Cognitive evaluation of the SST attributes has been identified as perception of service quality (Dabholkar 1996; Yen 2005) and therefore, the authors measured the influence of these attributes on satisfaction towards to SST. Accordingly, previous studies have found the effect of SST quality on customer satisfaction (Meuter et al. 2000; and Miguel-Dávila et al. 2010) in the retail environment (Mols 1998; and Yen 2005), and banking environment (Al-Hawari et al. 2006). Accordingly, investigation of SST literature identified SST attributes pertaining to the retail banking environment which act as service quality dimensions and ultimately influence customer satisfaction.

Meuter et al. (2000) mentioned that ability to perform the transactions more quickly in the SST environment compared to the interpersonal service environment increases customer satisfaction. Further, Yen (2005) has found that the efficiency attribute of SST environment leads to customer satisfaction. Accordingly, consumers are expected to be satisfied with SST if they perceive there to be efficiency in the self-service technology environment (Weijters et al. 2007; and Weijters et al. 2005). Moreover, perceived waiting time, which is associated with the efficiency aspect of the SST in the retail setting, has a positive influence on customer satisfaction (Buell et al. 2010). Further, Eriksson and Nilsson (2007) found that the convenience dimension, which represent the usefulness of SST, has a positive influence on multichannel SST satisfaction. Accordingly, researchers postulate that,

H1: Efficiency of SST has a positive effect on customer satisfaction towards service provided by commercial retail banks in Sri Lanka. 
Ease of use of a system largely determines the attitudes of consumers towards SST (Davis 1986) and thereby satisfaction with its usage. In an e-commerce setting, Devaraj et al. (2002) found a positive relationship between perceived ease of use and customer satisfaction while creating positive evaluation towards the online channel. Meanwhile, Yen (2005) has also found that a positive relationship between the SST attribute of perceived easiness to use and customer satisfaction. Meanwhile, academic researchers have found a strong positive relationship between perceived ease of use and continued intention to use the SST service offered by banks (see for El-Kasheir et al. 2009). Additionally, perceived ease of use has been found to be one of the strongest predictors of formation of attitude towards SST and thereby actual usage of a system because of customer satisfaction (Weijters et al. 2007). Therefore, researchers postulate that,

H2: Ease of use of SST has a positive effect on customer satisfaction towards service provided by commercial banks in Sri Lanka

The dimension of reliability is found to be the important attribute in assessing the quality of a service environment and researchers have found that there is a positive influence of the reliability of SST attribute on customer satisfaction (Meuter et al. 2000; Yen 2005). Likewise, reliability is found to be one of the strong predictors of continuous usage and thereby influencing customer satisfaction in the retail context (Weijters et al. 2007). Nguyen et al. (2014) found that customer satisfaction towards to usage of ATM machines is influenced by the attribute reliability. Meanwhile, accuracy of service rendered by the SST service environment has been shown to have a positive relationship with customer satisfaction (Collier and Kimes 2012). Therefore, researchers postulate that,
H3: Reliability of SST has a positive effect on customer satisfaction towards service provided by commercial banks in Sri Lanka

Further, it has been found that customers feel satisfied with SST if it provides the service when and where they want it (Meuter et al. 2000). Accordingly, Yen (2005) has found that there is a positive relationship between the convenience attribute of internet mediated SST service encounter environment and customer satisfaction. Further, there is evidence that supports the idea that attribute convenience stemming from the SST service environment acts as a driver of customer satisfaction (Collier and Sherrell 2010). Further, convenience of SST has an influence on customer satisfaction (Wang 2012). Accordingly, researchers postulate the fourth hypothesis,

H4: Convenience of SST has a positive effect on customer satisfaction towards service provided by commercial banks in Sri Lanka

The perceived security of SSTs determines the acceptance (Dixit and Datta 2010) and usage of SST to conduct transactions by customers. Reduction of perceived risk of SST (avoidance of losing personal information and improper usage of information by third parties) leads to customers intending to use them and therefore customer satisfaction. Further, privacy and security of the ATM environment leads to customer satisfaction regarding financial need among Jordanian customers (Al-Sawalqa 2012). Secure features available in an SST environment have also been shown to affect service quality perception and satisfaction towards SST services (Liljander et al. 2002). Accordingly, the researchers have proposed a fifth hypothesis as.

H5: Security of SST has a positive effect on customer satisfaction towards services provided by commercial banks in Sri Lanka. 
Figure 1. Conceptual Model Developed by the Researcher

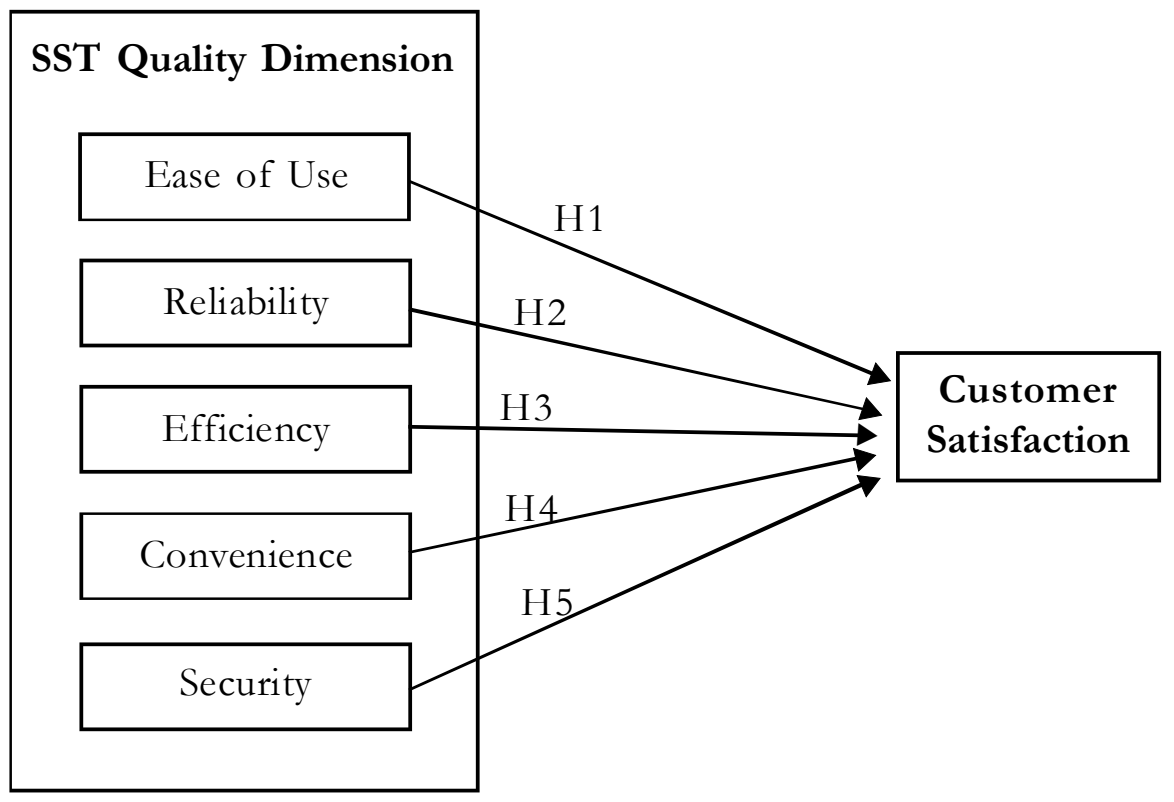

\section{Methods}

The proposed model was tested by collecting data from the customers who use different banking self-service technologies in Sri Lanka. Growing deployment of SST among commercial banks in Sri Lanka had driven this study and observations have also provided evidence of higher usage of the same technology among the customers of these banks.

\section{Sample and Survey Procedure}

This study was empirical in nature and a survey method was employed to collect the data. Data for this study were obtained from six selected bank branches located in Western Province in Sri Lanka. Sekaran and Bougie (2010, p. 296) cites that Roscoe (1975) proposed a "sample size larger than 30 and less than 500 is appropriate for most research" and most of the researchers suggest its appropriateness for conducting multivariate research analysis. Accordingly, to collect data from customers who are using SST in Sri
Lanka, six top Sri Lankan commercial banks were selected on the basis of key financial data published by Thalgodapitiya and Bhoumik (2012) and www.cse.lk (key performance data in 2012). Accordingly, Bank of Ceylon (BOC), People's Bank (PB), Commercial Bank (CB), Hatton National Bank (HNB), Seylan Bank (SB) and Sampath Bank (SB) were selected for this study. Bank branches were selected from Western Province and it was revealed that each bank had its own specific customer data base and records of customers were found to be regularly updated making the infinite population. Further, it revealed the dispersion of usage of SSTs by the customer. Hence, sixty (60) respondents were randomly selected from the data bases of each bank while getting the support from the branch managers of these banks. At the point of time, the registered users of the banks' SST were considered to be the infinite population (Anderson et al. 2011). A total of 360 respondents was selected from these banks and while selecting 
the customers, a special filtering approach was applied by the mangers to select the customers who are having at least ATM transactions with the respective bank. Each customer was accessed with the help of the bank's customer officers. Further, a few questionnaires were sent to customers' personal addresses enclosing return address envelopes. A power analysis level of 0.80 suggested by Cohen et al. (2003) was applied to determine the sample size that would provide adequate statistical power for testing the hypothesis.

\section{Measures}

This study was based on the pre-existing concepts in the literature and the scale items were developed largely with the help of literature and preliminary in-depth interviews. The SST quality dimensions and satisfaction items used in this study were extracted from different research findings (refer to Table 2). A total of 19 items was identified to measure the five dimensions proposed to be used to measure the SST quality of banks: ease of use, efficiency, reliability, security and convenience. Ease of use is operationalized as having 5 items adapted from Gefen and Straub (2000); Oghazi et al. (2012); Chang and Chang (2013); Davis (1986); Venkatesh (2000); Venkatesh et al. (2002); Lin and Hsieh (2011); and Al-Hawari et al. (2009). Efficiency dimensions consist of 4 items adapted from Al-Hawari et al. (2009), Miguel-Dávila et al. (2010), Ganguli and Roy (2011), Kim and Lim (2001), Parasuraman et al. (2005), Bitner (1990), Bitner et al. (1997) and Yen (2005). To measure the reliability, this study uses 4 items adapted from Chang et al. (2009), Ganguli and Roy (2010), Yang et al. (2004), Santos (2003), Van Riel et al. (2003) and Dabholkar and Bagozzi (2002). Security is measured with the support of 3 items adapted from Ganguli and Roy (2010); Yang et al. (2004); Kumar and Bose (2013); and Li and Suomi (2009). Finally, convenience is measured with the 3 items derived from Ganguli and Roy (2010); and Meuter et al. (2000). In addition to that, customer satisfaction is measured with 3 items adapted from Chang et al. (2009); Özer et al. (2013); and Cronin et al. (2000). The generated items were then subjected to review by two academic experts in Information System environments and two IT managers from two selected banks. All measures were measured with five point scales $(1=$ strongly disagree, $2=$ disagree, $3=$ neutral, $4=$ agree and $5=$ strongly agree). Similarly, the questionnaire used in this study had closed-ended questions, which included usage behavior of SST alternatives and the respondents' demographic details.

The scale developed to measure the SST quality and satisfaction was subjected to a refining process in order to ensure the psychometric properties. Generally, items placed in the questionnaire were positively perceived by the respondents. Mean values calculated for the five dimensions tend to show that respondents agree with the statements in the questionnaire. Additionally, the researchers tested the reliability and validity of the scale by administering the survey instrument to 50 customers before the survey. Cronbach's alpha coefficient was utilized to identify the reliability status of each dimension that measures the bank's SST quality. Coefficient alpha range from $0-1$ and Gliem and Gliem (2003) citing Darren and Mallery (1999) proposed a rule of thumb; " $\rightarrow 0.9$ (Excellent), $\rightarrow 0.8$ (Good), $\rightarrow 0.7$ (Acceptable), $\rightarrow 0.6$ (Questionable), $\rightarrow 0.5$ (Poor), and $\rightarrow 0.5$ (Unacceptable)." Questionnaires were piloted with 50 respondents. Initial reliability statistics pertaining to the concepts used in this study are in the following table (Table 3). 
Table 2. SST Quality and Satisfaction Items

\section{Service Quality Dimensions and Items}

\section{Ease of Use}

It is easy to become expert using Self Service Technology provided by my bank(Gefen and Straub 2000; Oghazi et al. 2012)

I find that my bank's self-service technologies are easy to use(C-C. Chang and Chang 2013; F. D. Davis 1986; Gefen and Straub 2000; Oghazi et al. 2012; Venkatesh 2000; and Venkatesh et al. 2002)

My bank's self-service technologies has clear instructions(Al-Hawari et al. 2009; Lin and Hsieh 2011; Oghazi et al. 2012; and Venkatesh et al. 2002)

Self Service Technology provided by my bank is user-friendly (Venkatesh 2000)

Interacting with the system does not require a lot of my mental effort (Venkatesh 2000; and Venkatesh et al. 2002)

\section{Efficiency}

My bank's Self Service Technology provides quick service with taking shorter waiting time (Al-Hawari et al. 2009; and Miguel-Dávila et al. 2010)

Self Service Technology of my bank save my time (Ganguli and Roy 2010; S. Y. Kim and Lim 2001; and Parasuraman et al. 2005)

My bank's Self Service Technology allows me to complete transactions quickly (Ganguli and Roy 2010; S. Y. Kim and Lim 2001; and Parasuraman et al. 2005)

My bank's self- service technology reduce the cost of my activities with the bank (Mary Jo Bitner et al. 1997; and Yen 2005)

\section{Reliability}

I obtain accurate and error free service from my bank's SST (H. H. Chang et al. 2009; Ganguli and Roy 2010; and Yang et al. 2004)

I can depend on the service provides over the bank's SST (Expert insights)

My bank's SST completes my transaction specified in designated time (Chang et al. 2009; Santos 2003; Van Riel et al. 2003; and Yang et al. 2004)

My bank's SST is reliable (Dabholkar and Bagozzi 2002; Ganguli and Roy 2010; and Yang et al. 2004)

\section{Security}

I feel safe using my bank's SST(Ganguli and Roy 2010; Yang et al. 2004; and Kumar and Bose 2013)

Risk associated with my bank's SST is low (Ganguli and Roy 2010; Li and Suomi 2009; and Yang et al. 2004)

Personal information exchanged over SST is not misused by bank (Ganguli and Roy 2010; and Yang et al. 2004) 


\section{Table 2 (Continued)}

\section{Convenience}

My bank's Self Service Technology is accessible beyond regular business hours (Ganguli and Roy 2010; and Meuter et al. 2000)

My bank's SST provide allows me to do the transactions anywhere (Ganguli and Roy 2010; and Meuter et al. 2000)

My bank's SST is convenient(Ganguli and Roy 2010; and Meuter et al. 2000)

\section{Satisfaction}

Overall I'm satisfied with my bank's SST (Chang et al. 2009; Özer et al. 2013; and Yen 2005)

I made the right decision to use my bank's SST (Chang et al. 2009; and Cronin et al. 2000)

I can easily recommend my bank's SST to my friends and others(Özer et al. 2013)

Table 3. Reliability Statistics

\begin{tabular}{lcl}
\hline Dimensions & $\begin{array}{c}\text { No } \\
\text { of items }\end{array}$ & $\begin{array}{c}\text { Cronbach's } \\
\text { Alpha }\end{array}$ \\
\hline Reliability & 5 & 0.756 \\
Ease of use & 3 & $\begin{array}{l}\text { Initially .688 } \\
\text { and later.710 }\end{array}$ \\
Security & 3 & 0.738 \\
Efficiency & 3 & 0.857 \\
Convenience & 3 & 0.761 \\
Satisfaction & 3 & 0.701 \\
\hline
\end{tabular}

Except for the ease of use dimension, the reliability of the results of other dimensions were reported under the acceptable level at the initial stage and items were modified to make it more clear and understandable in Sinhala language and so that modification revealed the acceptable higher alpha value.

Accuracy of the measurement represents the validity. Firstly, Bannigan and Watson (2009) cites McDowell and Newell (1996): 'A variety of approaches should be used in testing any index, rather than relying on a single validation procedure.' Therefore, construct items were reviewed by two academics who represent the behavioral aspects of technology and two IT managers to ensure the content and face validity. Construct validity was assessed through factorial validity (Bannigan and Watson 2009) and this was facilitated by exploratory factor analysis. In particular, the study performed a Principal Component Analysis (PCA) with varimax rotation since it is similar to factor analysis. PCA represents the larger number of relationships among interval data in a more parsimonious way (Leech et al. 2005). Initial investigation of a correlation matrix of SST quality structure, namely ease of use, reliability, efficiency, convenience and security, revealed the factorability and showed five interpretable components.

Secondly, Kaiser-Meyer-Olkin (KMO) measure of sampling adequacy and Bartletts Test of Sphericity (BTS) were performed. The Kaiser-Meyer-Olkin measure of sampling adequacy was 0.663 (this was above the recommended value of 0.6 ) and Bartlett's test 
of Sphericity was significant $\left(\chi^{2}(2161.865)=\right.$ 171, $p<0.05)$. Thirdly, factor extraction was performed and it was based on multiple criteria namely Kaiser's rule (eigenvalues $>1$ rule) and cumulative percent of variance extracted. Accordingly, the five factor solution resembled the proposed dimensions and explained 68.093 percent variance with 18.011 percent, 15.976 percent, 12.894 percent,
11.550 percent and 9.663 percent for efficiency, ease of use, reliability convenience and security respectively. All the factor loadings were above the recommended cut of criteria 0.40 (Hair et al. 2006) ranging from 0.631 to 0.902 suggesting five factors as proposed by the researchers. Items and their respective loadings on each dimension are given in the Table 4.

\section{Table 4. Principle Component Analysis}

\begin{tabular}{|c|c|c|c|c|c|c|}
\hline & Variable and Items & 1 & 2 & 3 & 4 & 5 \\
\hline & Efficiency & & & & & \\
\hline E1 & $\begin{array}{l}\text { My bank's Self Service Technology provides quick } \\
\text { service with taking shorter waiting time }\end{array}$ & 0.883 & & & & \\
\hline E2 & Self Service Technology of my bank save my time & 0.876 & & & & \\
\hline E3 & $\begin{array}{l}\text { My bank's Self Service Technology allows me to } \\
\text { complete transactions quickly }\end{array}$ & 0.940 & & & & \\
\hline E4 & $\begin{array}{l}\text { My bank's self- service technology reduce the cost } \\
\text { of my activities with the bank }\end{array}$ & 0.839 & & & & \\
\hline E1 & $\begin{array}{l}\text { Ease of Use } \\
\text { It is easy to become expert using Self Service } \\
\text { Technology provided by my bank }\end{array}$ & & 0.792 & & & \\
\hline E2 & $\begin{array}{l}\text { I find that my bank's self-service technologies are } \\
\text { easy to use }\end{array}$ & & 0.831 & & & \\
\hline E3 & $\begin{array}{l}\text { My bank's self-service technologies has clear } \\
\text { instructions }\end{array}$ & & 0.675 & & & \\
\hline E4 & $\begin{array}{l}\text { Self Service Technology provided by my bank is } \\
\text { user-friendly }\end{array}$ & & 0.743 & & & \\
\hline E5 & $\begin{array}{l}\text { Interacting with the system does not require a lot } \\
\text { of my mental effort }\end{array}$ & & 0.632 & & & \\
\hline $\mathrm{C} 1$ & $\begin{array}{l}\text { Convenience } \\
\text { My bank's Self Service Technology is accessible } \\
\text { beyond regular business hours }\end{array}$ & & & 0.898 & & \\
\hline $\mathrm{C} 2$ & $\begin{array}{l}\text { My bank's SST provide allows me to do the } \\
\text { transactions anywhere }\end{array}$ & & & 0.894 & & \\
\hline C3 & My bank's SST is convenient & & & 0.902 & & \\
\hline
\end{tabular}


Table 4 (Continued)

\begin{tabular}{|c|c|c|c|c|c|c|}
\hline & Variable and Items & 1 & 2 & 3 & 4 & 5 \\
\hline R1 & $\begin{array}{l}\text { Reliability } \\
\text { I obtain accurate and error free service from my } \\
\text { bank's SST }\end{array}$ & & & & 0.879 & \\
\hline R2 & I can depend on the service provides over the bank's & SST & & & 0.682 & \\
\hline R3 & $\begin{array}{l}\text { My bank's SST completes my transaction specified in } \\
\text { designated time }\end{array}$ & & & & 0.631 & \\
\hline R4 & My bank's SST is reliable & & & & 0.831 & \\
\hline & Security & & & & & \\
\hline S1 & I feel safe using my bank's SST & & & & & 0.801 \\
\hline S2 & Risk associated with my bank's SST is low & & & & & 0.890 \\
\hline S3 & $\begin{array}{l}\text { Personal information exchanged over SST is not } \\
\text { misused by bank }\end{array}$ & & & & & 0.729 \\
\hline & Eignevalues & 3.422 & 3.035 & 2.450 & 2.194 & 1.836 \\
\hline & $\%$ of variance Explained & 18.011 & 15.976 & 12.894 & 11.550 & 9.663 \\
\hline
\end{tabular}

\section{Results and Discussion}

\section{Descriptive Analysis}

For the final survey, a total of 215 survey questionnaires were collected, while 145 questionnaires were eliminated. The survey response rate was 59 percent (refer Table 3). Usage behavioral data, along with the demographic data pertaining to respondents, that were included in this study were as follows: gender, age, educational status, occupation, disposable income, mostly used SST, period of interaction with bank's SST and activities perform over the SST. Nevertheless, almost 64.65 percent respondents belonged to the age level of $18-30$. About half $(49.30 \%)$ of the total respondents were Ordinary Level and Advanced Level qualified persons. About 63.25 percent of the respondents were employed in the private sector, 19.06 percent were employed in the government sector and
9.30 percent of the respondents were selfemployed. The rest of the respondents $(8.37 \%)$ were unemployed. Regarding disposable income, about 68.83 percent of the respondents had an income of 25001-50000. In terms of usage, 75.34 percent of the respondents had less than six months' experience with SMS banking and Internet banking activities. Yet, more than one year experience was reported with ATM and Automated Telephone banking services. Respondents were using more than one SST to interact with their respective banks and ATM was recognized as the most utilized SST banking $(100 \%)$ followed by SMS banking (79.06\%), Internet banking (44.65\%) and Automated Telephone Banking (33.02\%) from the total sample. Viewing account balance (100\%), obtaining money (100\%), payment of utility bills $(36 \%)$ and fund transfer $(21 \%)$ were represented as the major banking SST activities among the respondents (Table 5). 
Table 5. Demographic Attributes of the Sample

\begin{tabular}{lcc}
\hline Attribute & $\begin{array}{c}\text { Frequency } \\
(\boldsymbol{n}=\mathbf{2 1 5})\end{array}$ & $\mathbf{\%}$ \\
\hline $\begin{array}{l}\text { Gender } \\
\text { Male }\end{array}$ & 151 & 70.2 \\
Female & 64 & 29.8 \\
Age & & \\
18-30 & 139 & 64.65 \\
$31-50$ & 51 & 23.72 \\
Over 51 & 25 & 11.63
\end{tabular}

\section{Educational Status}

$\begin{array}{lcc}\text { O/L \& A/L } & 106 & 49.30 \\ \text { Diploma } & 60 & 27.91 \\ \text { Basic Degree } & 37 & 17.21 \\ \text { Postgraduate Degree } & 12 & 5.58\end{array}$

\section{Profession}

$\begin{array}{lrr}\text { Self Employed } & 20 & 9.30 \\ \text { Employed in Private } & & \\ \text { Sector } & 136 & 63.26 \\ \text { Employed in Government } & & \\ \text { Sector } & 41 & 19.07 \\ \text { Unemployed } & 18 & 8.37\end{array}$

\section{Monthly Income}

Less than 25000

Between 25001-50000

Between $50001-75000$

\section{SST Usage Experience}

Less than 6 Months

Less than one year and

more than 6 months

More than one year

\section{Results}

The primary concern of this study was to assess the effect of SST quality dimensions on customer satisfaction. Hence, multiple regression analysis was conducted to test the hypothesized relationships. Residuals were checked for normality to assess the suitability of the regression model. Accordingly, SST quality (Table 6) dimensions helped to explain 17 percent (adjusted R squared .154) of the customers satisfaction. The regression model was significant at 0.05 level $(F(5,209)=$ 8.784). Further, post hoc power analysis was conducted with GPower package (Faul et al. 2007) and revealed that power to detect obtained effects at the 0.05 level was 0.99 for the overall regression in prediction of satisfaction.

The coefficient table shows (Table 6) the contribution of each SST quality dimension in explaining customer satisfaction. The predictor ease of use $(b=0.009)$ was not significant $(\mathrm{P}>0.05, \mathrm{t}=0.133)$. This has rejected the first hypothesis (H1) formulated by the researchers: ease of use of SST has a positive effect on customer satisfaction towards service provided by commercial banks in Sri Lanka. Next, the effect of reliability $(b=0.305)$ was a significant $(\mathrm{P}<0.05, \mathrm{t}=4.784)$ predictor and it was the major contributing variable for the customer satisfaction. With that, the researchers have accepted the second hypothesis (H2): Reliability of SST has a positive effect on customer satisfaction towards service provided by commercial banks in Sri Lanka. Predictor, security $(\mathrm{b}=0.011)$ was not a significant variable $(\mathrm{P}>0.005, \mathrm{t}=0.164)$. This has rejected the fifth hypothesis (H5) formulated by the researchers: Security of SST has a positive effect on customer satisfaction towards service provided by commercial banks in Sri Lanka. Yet, convenience dimension $(b=0.212)$ had a significant 
Table 6. Coefficients

\begin{tabular}{lccccc}
\hline Model & $\begin{array}{c}\text { Standardized } \\
\text { Coefficients } \\
\text { Beta }\end{array}$ & $\mathbf{t}$ & Sig. & \multicolumn{2}{c}{$\begin{array}{c}\mathbf{9 5 . 0 \%} \text { Confidence Interval } \\
\text { for B }\end{array}$} \\
\cline { 5 - 6 } & & 6.321 & 0.000 & 1.274 & $\begin{array}{c}\text { Lower } \\
\text { Bound }\end{array}$ \\
\hline (Constant) & 0.009 & 0.133 & 0.895 & -0.083 & $\begin{array}{c}\text { Upper } \\
\text { Bound }\end{array}$ \\
EaseofUse & $\mathbf{0 . 3 0 5}$ & 4.784 & $\mathbf{0 . 0 0 0}$ & $\mathbf{0 . 1 1 0}$ & $\mathbf{0 . 2 6 5}$ \\
Reliability & 0.011 & 0.164 & 0.870 & -0.092 & 0.109 \\
Security & $\mathbf{0 . 2 1 2}$ & $\mathbf{3 . 3 6 3}$ & $\mathbf{0 . 0 0 1}$ & $\mathbf{0 . 0 5 1}$ & $\mathbf{0 . 1 9 5}$ \\
Convenience & $\mathbf{- 0 . 1 3 7}$ & $\mathbf{- 2 . 1 6 3}$ & $\mathbf{0 . 0 3 2}$ & $\mathbf{- 0 . 1 2 3}$ & $\mathbf{- 0 . 0 0 6}$ \\
Efficiency & & & & & \\
\hline
\end{tabular}

$R=0.416,{ }^{a} R$ Square 0.173, Adjusted R Square 0.154, $F=8.784$, df1 5 and df2 209, $P=0.000$

b. Dependent Variable: Satisfaction

a. Predictors: (Constant), Efficiency, Ease of Use, Convenience, Reliability, Security

$(\mathrm{P}<0.001, \mathrm{t}=3.363)$ positive effect on customer satisfaction. It was the second major contributing service quality dimension that influenced customer satisfaction in self-service technological environment of banks. This persuaded the researchers to accept the fourth hypothesis (H4): Convenience of SST has a positive effect on customer satisfaction towards service provided by commercial banks in Sri Lanka. Finally, efficiency dimension was having a negative $(b=-0.137)$ significant $(P<0.05, t=$ 2.163) effect on customer satisfaction. Therefore researchers rejected the third hypothesis (H3): Efficiency of SST has positive effect on customer satisfaction towards service provided by commercial banks in Sri Lanka.

According to the results, the researchers have found that, among the selected banking self-service technology quality dimensions, reliability and convenience dimensions were having positive effects on customer satisfaction. Yet, it was revealed that efficiency dimension had a negative effect on customer satisfaction. Other dimensions, security and ease of use were found to be non-influential quality dimensions of customer satisfaction.

\section{Conclusion and Implications}

\section{Conclusion}

This study attempted to build a scale to measure perceived self-service technology quality dimensions in the retail banking environment in Sri Lanka. Rather than considering each SST service environment separately, this study was focused on all the SST channels. Accordingly, the researchers proposed five service quality dimensions considering all banking self-service technologies and adopted the attribute base approach proposed by Dabholkar (1996) to assess the quality of self-service technology. It was found that consumers evaluate service quality of the SST of banks by considering the efficiency, ease of use, convenience, reliability and security. This study considered efficiency as an important attribute for evaluating the SST, though other studies have not taken it into consider- 
ation. PCA results i.e. identified attributes, were complemented with the previous research findings in the literature (Dabholkar 1996; Ganguli and Roy 2011; Lin and Hsieh 2011; Meuter et al. 2000; Oghazi et al. 2012; Shamdasani et al. 2008; Venkatesh 2000; and Yang et al. 2004; Yen 2005). In the second part of this study, the researchers tried to find out the effect of SST quality dimensions on customer satisfaction. Mainly it was revealed that the quality of SST has an effect on customer satisfaction and this was consistent with the findings of the other research studies (Chang et al. 2009; and Dabholkar et al. 2000). This model helps to explain 17 percent of the variance of customer satisfaction (Cohen et al. 2003) and suggests acceptable value for the social science research setting (Gaur and Gaur 2009).

Further, this study assessed the effect of separate SST quality dimensions on customer satisfaction in order to explore the relative contribution to explain the explanatory variable. Accordingly, regression analysis revealed the importance of reliability and convenience dimensions to create customer satisfaction. Reliability of the service was largely ensured through the perceived completion of the transaction in the SST environment equivalent to the traditional service environment. This ensured the customer satisfaction. Customer satisfaction was also driven by convenience provided by the banks' SST which ultimately provides accessibility to the bank beyond the regular business hours from anywhere in the country. Further, dimensions of ease of use and security had no significant effect on customer satisfaction. This was similar to the findings of Chang and Chang (2013) where they have found that perceived security have no effect on intention to use the online financial services. Despite that, this study has produced contradictory findings.
This was the negative effect of efficiency on customer satisfaction. The reason for this may be that customers do not need to save their money or save their time by accessing the bank's SST since it provides basic services to them. This was somewhat similar to the idea of Buell et al. (2010) and the authors cite Hitt and Frei (2002) studies have found high customer time involvement in the online environment compared to the offline environment. Therefore, it can be concluded that money saving as well as time saving do not contribute to the customer satisfaction in the self-service environment but contribute negatively. Further this study contributed to the current literature. Mainly, it viewed the service quality as a multidimensional concept and supported the existing literature. In addition to that, studies which capture the generic quality of all the self-service channels are limited. Many researchers have made it their priority to study service quality of the internet based self-service while limiting the investigation into other service channels. Further, many of the studies of SST quality assessments were conducted in developed countries and not in developing countries. Given that, this study was confined to Sri Lanka which is recognized as a developing country. Therefore, this study filled the gaps in the current literature by providing insights from growing economic perspectives.

\section{Implications}

From managerial perspectives, this study provides banking marketing managers and supportive IT managers a theoretical insight into the quality levels of SST banking activities. This ultimately helps them to reconsider their approaches. Continuous maintenance and effective communication should be there to maintain the reliability as well as convenience of the service delivered over the 
banks SST which ultimately increase the customer satisfaction. Reliability of the service can be enhanced through providing accurate presentations of figures and facts through enhancing the technical functionalities of the systems. Convenience can be enhanced by establishing more ATM machines and Kiosks in different locations in the country as well as by providing common ATM platforms to users by merging system of different banks. Despites that, managers need to increase the perceived ease of use and perceived security of the system.

\section{Research Limitations and Future Research}

There are several limitations of this study and they should be considered before interpreting the research findings. Mainly, this study was limited to Western Province in Sri Lanka and consideration should be given to this aspect while generalizing the findings. In addition to that, the study was limited to six banks in Sri Lanka but there are other foreign and domestic banks which offer self-service banking facilities to the Sri Lankan customers. This will limit the ability to generalize the findings. In addition to that, this study was confined to assessing the generic selfservice technologies rather than the specific self-service technology quality such as call center service quality, SMS banking service quality, and Internet banking service quality etc. separately. It is recognized that each of the services associates with different technologies and different quality perception (Kumar and Bose 2013). This broader perspective was not addressed through this study. Other than the service quality, there are other factors which determine customer satisfac- tion in the retail banking environment. These factors were not tested and observed in this research. Managers and other strategists should consider getting the customer engagement on designing the self-service technology channels for their banks and this will ultimately help them to respond to the customer needs better than their competitors. Finally, this study was limited to the retail banking sector and this selection of one industry made the findings limited in terms of building up a general picture of usage of self-service technology within the Sri Lankan environment.

This study sheds light on the other studies. Mainly, other than the dimensions identified, there are other attributes that could influence evaluating self-service technology. Therefore, future researchers can find and validate other attributes that customers use to judge the service quality in self-service technological environments. Self-service technologies are also increasingly being adopted by the business to business sector in their transactions (Meuter et al. 2000) and therefore studies can extend to business to business environments too. It is also important to understand the factors that influence customers to adopt self-service technologies in the banking environment rather than using traditional banking services. Additional research also can be carried out to examine the quality-loyalty relationship as a whole to shed more light on e-service quality and its behavioral consequences. Introduction of self-service technologies increases the distance of customers from the service organizations and therefore the implications of distancing a customer from the interpersonal service delivery also can be studied. 


\section{Acknowledgement}

Researchers would like to pay special appreciation for advises provided by Dr.C.N. Wickramasinghe for the subsequent development of this paper.

\section{References}

Al-Hawari, M. A. 2011. Automated service quality as a predictor of customers' commitment: A practical study within the UAE retail banking context. Asia Pacific Journal of Marketing and Logistics 23 (3): $346-66$

Al-Hawari, M. A., T. Ward, and L. Newby. 2009. The relationship between service quality and retention within the automated and traditional contexts of retail banking. Journal of Service Management 20 (4): 455-72. doi:10.1108/09564230910978539.

Al-Hawari, M. A., N. Hartley, and T. Ward. 2005. Measuring banks' automated service quality: A confirmatory factor analysis approach. Marketing Bulletin 16: 1-19.

Al-Hawari, M. A., and T. Ward. 2006. The effect of automated service quality on Australian banks' financial performance and the mediating role of customer satisfaction. Marketing Intelligence and Planning 24 (2): 127-47. doi:10.1108/02634500610653991.

Al-Sawalqa, F. 2012. Customers' financial needs satisfaction and self-service technology banking: The case of automatic teller machines (ATMs) in Jordan. International Journal of Business and Social Science 3 (9): $191-200$.

Anderson, D., D. Sweeney, and T. Williams. 2011. Essentials of Modern Business Statistics with Microsoft Excel ( $5^{\text {th }}$ ed.). Cengage Learning. http://www.cengage.com/search/productOverview.do; jsessionid=45BEF980D6754C40930FC56D5756B9CC?N=

$11 \& \mathrm{Ntk}=$ all $\mid$ P_Isbn13\&Ntt=9780840062383\&Ntx=mode + matchallpartial.

Anderson, E. W., C. Fornell, and D. R. Lehmann. 1994. Customer satisfaction, market share, and profitability: Findings from Sweden. Joumal of Marketing 58: 53-66. doi:10.2307/1252310.

Andreassen, T. W. 2000. Antecedents to satisfaction with service recovery. European Journal of Marketing 34 (1/2): 156-75. doi:10.1108/03090560010306269.

Baker, D. A., and J. L. Crompton. 2000. Quality, satisfaction and behavioral intentions. Annals of Tourism Research 27: 785-804. doi:10.1016/S0160-7383(99)00108-5.

Bannigan, K., and R. Watson. 2009. Reliability and validity in a nutshell. Journal of Clinical Nursing 18 (23): 3237-43. doi:10.1111/j.1365-2702.2009.02939.x.

Bateson, J. E. G. 1985. "Self-service consumer: An exploratory study. Journal of Retailing 61: 49-76.

Beatson, A., N. Lee, and L. V. Coote. 2007. Self-service technology and the service encounter. The Service Industries Journal. doi:10.1080/02642060601038700.

Bitner, M. J., S. W. Brown, and M. L. Meuter. 2000. Technology infusion in service encounters. Journal of the Academy of Marketing Science 28 (1): 138-49. doi:10.1177/0092070300281013.

Bitner, M. J. 1990. Evaluating service encounters: The effects of physical surroundings and employee responses. The Journal of Marketing: 69-82. 
Bitner, M. Jo, W. T. Faranda, A. R. Hubbert, and V. A. Zeithaml. 1997. Customer contributions and roles in service delivery. International Journal of Service Industry Management 8 (3): 193-205.

Bobbitt, L. M., and P. A. Dabholkar. 2001. Integrating attitudinal theories to understand and predict use of technology-based self-service: The internet as an illustration. International Journal of Service Industry Management 12 (5): 423-50. doi:10.1108/EUM0000000006092.

Buell, R. W., D. Campbell, and F. X. Frei. 2010. Are self-service customers satisfied or stuck? Production and Operations Management 19 (2): 679-97. doi:10.1111/j.1937-5956.2010.01151.x.

Chang, C-C., and P. C. Chang. 2013. A study on Taiwan consumers' adoption of online financial services. Asia Pacific Management Review 18: 197-220. doi:10.6126/APMR.2013.18.2.05.

Chang, H-H., Y-H. Wang, and W-Y. Yang. 2009. The impact of e-service quality, customer satisfaction and loyalty on e-marketing: Moderating effect of perceived value. Total Quality Management and Business Excellence 20 (4): 423-43. doi:10.1080/14783360902781923.

Cheng, B-L., Z. Abdul, and Md. Z. Abdul Rashid. 2013. Service quality and the mediating effect of corporate image on the relationship between customer satisfaction and customer loyalty in the Malaysian hotel industry. Gadjah Mada International Journal of Business 15 (2): 39-51. http:// eds.b.ebscohost.com/eds/pdfviewer/pdfviewer? sid=3199ff67-cfd0-4b6a-a9ed70cf309f5407\%40sessionmgr110\&vid $=18 \&$ hid $=109$.

Cohen, P., J. Cohen, S. G. West, and L. S. Aiken. 2003. Applied Multiple Regression / Correlation Analysis for the Behavioral Sciences (2 $2^{\text {nd }}$ ed.). Hillsdale NJ Lawrence Erlbaum Associates. http://books.google.com/ books?hl=de\&lr=\&id=fuq94a8C0ioC\&pgis $=1$.

Collier, J. E., and S. E. Kimes. 2012. Only if it is convenient: Understanding how convenience influences self-service technology evaluation. Journal of Service Research 16 (1): 39-51. doi:10.1177/ 1094670512458454.

Collier, J. E., and D. L. Sherrell. 2010. Examining the influence of control and convenience in a selfservice setting. Journal of the Academy of Marketing Science 38 (4): 490-509. doi:10.1007/s11747-0090179-4.

Cronin, J., M. Brady, G. Hult, and M. Tomas. 2000. Assessing the effects of quality, value, and customer satisfaction on consumer behavioral intentions in service environments. Journal of Retailing 76: 193 218. doi:10.1016/s0022-4359(00)00028-2.

Curran, J. M., M. L. Meuter, and C. F. Surprenant. 2003. Intentions to use self-service technologies: A confluence of multiple attitudes. Journal of Service Research 5 (3): 209-24. doi:10.1177/ 1094670502238916.

Dabholkar, P. A, C. D. Shepherd, and D. I. Thorpe. 2000. A comprehensive framework for service quality: An investigation of critical conceptual and measurement issues through a longitudinal study. Journal of Retailing 76 (2): 139-73. doi:10.1016/S0022-4359(00)00029-4.

Dabholkar, P. A. 1996. Consumer evaluations of new technology-based self-service options: An investigation of alternative models of service quality. International Journal of Research in Marketing 13: 29_ 51. doi:10.1016/0167-8116(95)00027-5.

Dabholkar, P. A., and R. P. Bagozzi. 2002. An attitudinal model of technology-based self-service: Moderating effects of consumer traits and situational factors. Journal of the Academy of Marketing Science 30: 184-201. doi:10.1177/0092070302303001.

Darren, G., and P .Mallery. 1999. SPSS for Windows Step by Step: A Simple Guide and Reference. 
Darsono, L. I., and C. M. Junaedi. 2006. An examination of perceived quality, satisfaction, and loyalty relationship: Applicability of comparative and noncomparative evaluation. Gadjah Mada International Joumal of Business 8 (3): 323-42.

Davis, F. D., R. P. Bagozzi, and P. R. Warshaw. 1989. User acceptance of computer technology: A comparison of two theoretical models. Management Science 35 (8): 982-1003. doi:10.1287/mnsc.35.8.982.

Davis, F. D. 1986. A technology acceptance model for empirically testing new end-user information systems: Theory and results. Doctoral Dissertation. Sloan School of Management MIT. http:// dspace.mit.edu/handle/1721.1/15192.

Devaraj, S., M. Fan, and R. Kohli. 2002. Antecedents of B2C channel satisfaction and preference: Validating e-commerce metrics. Information Systems Research 13 (3): 316-33.

Ding, D. X., P. J-H. Hu, and O. R. L. Sheng. 2011. E-SELFQUAL: A scale for measuring online selfservice quality. Journal of Business Research 64 (5): 508-15. doi:10.1016/j.jbusres.2010.04.007.

Dixit, N., and S. K. Datta. 2010. Acceptance of e-banking among adult customers: An empirical investigation in India. Journal of Internet Banking and Commerre 15: 1-17.

El-Kasheir, D., A. S. Ashour, and O. M. Yacout. 2009. Factors affecting continued usage of internet banking among Egyptian customers. Communications of the IBIMA: 252-63.

Eriksson, K., and D. Nilsson. 2007. Determinants of the continued use of self-service technology: The case of internet banking. Technovation 27 (4): 159-67. doi:10.1016/j.technovation.2006.11.001.

Faul, F., E. Erdfelder, A-G. Lang, and A. Buchner. 2007. G*Power 3: A flexible statistical power analysis program for the social, behavioral, and biomedical sciences. Behavior Research Methods 39: 175-91. doi:10.3758/BF03193146.

Fornell, C.. 1992. A national customer satisfaction barometer: The swedish experience. Journal of Marketing 1 (56): 6-21. doi:10.2307/1252129.

Fournier, S., and D. G. Mick. 1999. Rediscovering satisfaction. Journal of Marketing 63 (4): 5-23. doi:10.2307/ 1251971.

Ganguli, S., and S. K. Roy. 2010. Service quality dimensions of hybrid services. Managing Service Quality 20 (5): 404-24.

Ganguli, S., and S. K. Roy. 2011. Generic technology-based service quality dimensions in banking: Impact on customer satisfaction and loyalty. International Journal of Bank Marketing 29 (2): 168-89. doi:10.1108/ 02652321111107648.

Gaur, A. S., and S. S. Gaur. 2009. Statistical Methods for Practice and Research: A Guide to Data Analysis Using SPSS (B-42). Panchsheel Enclave, New Delhi 110017 India: SAGE Publications India Pvt Ltd. doi:10.4135/9788132108306.

Gefen, D., and D. W. Straub. 2000. The relative importance of perceived ease of use in IS adoption: A study of e-commerce adoption. Journal of the Association for Information Systems 1 (1). http:// aisel.aisnet.org/jais/vol1/iss1/8.

George, A., and G. S. G. Kumar. 2014. Impact of service quality dimensions in internet banking on customer satisfaction. Decision 41 (1): 73-85. doi:10.1007/s40622-014-0028-2.

Gliem, J., and R. Gliem. 2003. Calculating, interpreting, and reporting cronbach's alpha reliability coefficient for Likert-Type Scales. Midwest Research to Practice Conference in Adult, Continuing, and Community Education: 82-88. doi:10.1109/PROC.1975.9792. 
Hair, J. F., B. Black, B. Babin, R. E. Anderson, and R. L. Tatham. 2006. Multivariate Data Analysis (6 ${ }^{\text {th }}$ ed.). Upper Saddle River, NJ [etc.] / Pearson Prentice Hall.

Hitt, L. M., and F. X. Frei. 2002. Do better customers utilize electronic distribution channels? The case of PC banking. Management Science. doi:10.1287/mnsc.48.6.732.188.

Ho, S-H., and Y-Y. Ko. 2008. Effects of self-service technology on customer value and customer readiness: The case of internet banking. Internet Research. doi:10.1108/10662240810897826.

Johnson, D. S., F. Bardhi, and D. T. Dunn. 2008. Understanding how technology paradoxes affect customer satisfaction with self-service technology: The role of performance ambiguity and trust in technology. Psychology and Marketing 25: 41 6-43. doi:10.1002/mar.20218.

Kim, S. Y., and Young Jun Lim. 2001. Consumers' perceived importance of and satisfaction with internet shopping. Electronic Markets 11 (3): 148-54. doi:10.1080/101967801681007988.

Kim, S., and L. Stoel. 2004. Dimensional hierarchy of retail website quality. Information and Management 41: 619-33. doi:10.1016/j.im.2003.07.002.

Kumar, V. V. R., and S. K. Bose. 2013. Adoption of self service technologies (SST)-A study on the intention of management students to use internet banking services. Journal of Contemporary Research in Management 8 (1): 47-58.

Ledingham, J. A. 1984. Are consumers ready for the information age. Journal of Advertising Research 24 (4): 31-37.

Lee, G-G., and H-F. Lin. 2005. Customer perceptions of e-service quality in online shopping. International Joumal of Retail and Distribution Management. doi:10.1108/09590550510581485.

Lee, H. J., A. Fairhurst, and H. J. Cho. 2011. Gender differences in consumer evaluations of service quality: Self-service kiosks in retail. The Service Industries Journal. doi:10.1080/02642069.2011.614346.

Lee, H-J., A. E. Fairhurst, and M-Y. Lee. 2009. The importance of self-service kiosks in developing consumers' retail patronage intentions. Managing Service Quality 19 (6): 687-701. doi:10.1108/ 09604520911005071.

Leech, N. L., K. C. Barrett, and G. A. Morgan. 2005. SPSS for Intermediate Statistics: Use and Interpretation. Psychology Press.

Li, H., and R. Suomi. 2009. A proposed scale for measuring e-service quality. International Journal of $U$ - and E-Service, Science and Technology 2: 1-10. http://www.researchgate.net/publication/ 31598134_A_proposed_scale_for_measuring_e-service_quality/file/9fcfd508927437582e.pdf.

Liljander, V., A. C. R. van Riel, and M. Pura. 2002. Customer satisfaction with e-services: The case of an online recruitment portal. Electronic Services: 407-32. Springer. doi:10.1007/978-3-8349-4418-4.

Lin, J-S. C., and P-L. L. Hsieh. 2011. Assessing the self-service technology encounters: Development and validation of SSTQUAL scale. Journal of Retailing 87 (2): 194-206. doi:10.1016/j.jretai.2011.02.006.

McDowell, I., and C. Newell. 1996. Measuring Health: A Guide to Rating Scales and Questionnaires (2 ${ }^{\text {nd }}$ ed.). Oxford University Press.

Meuter, M. L., M. J. Bitner, A. L. Ostrom, and S. W. Brown. 2005. Choosing among alternative service delivery modes: An investigation of customer trial of self-service technologies. Journal of Marketing. doi:10.1509/jmkg.69.2.61.60759.

Meuter, M. L., A. L. Ostrom, R. I. Roundtree, and M. J. Bitner. 2000. Self-service technologies: Understanding customer satisfaction with technology-based service encounters. Journal of Marketing. doi:10.1509/jmkg.64.3.50.18024. 
Miguel-Dávila, J. Á., L. Cabeza-García, L. Valdunciel, and M. Flórez. 2010. Operations in banking: The service quality and effects on satisfaction and loyalty. The Service Industries Journal. doi:10.1080/ 02642060903289936.

Mols, N. P. 1998. The internet and the banks' strategic distribution channel decisions. Internet Research. doi:10.1108/10662249810231087.

Nguyen, N. T., T. T. Tran, and C. N. Wang. 2014. An empirical study of customer satisfaction towards bank payment card service quality in Ho Chi Minh banking branches. International Journal of Economics and Finance 6 (5). doi:10.5539/ijef.v6n5p170.

Oghazi, P., R. Mostaghel, M. Hultman, and V. Parida. 2012. Antecedents of technology-based self-service acceptance: A proposed model. Services Marketing Quarterly. doi:10.1080/15332969.2012.689937.

Oliver, R. L. 1993. Cognitive, affective, and attribute bases of the satisfaction response. Journal of Consumer Research. doi:10.1086/209358.

Oliver, R. 1980. A cognitive model of the antecedents and consequences of satisfaction decisions. Journal of Marketing Research XVII (4): 460-70. doi:10.2307/3150499.

Orel, F. D., and A. Kara. 2014. Supermarket self-checkout service quality, customer satisfaction, and loyalty: Empirical evidence from an emerging market. Journal of Retailing and Consumer Services 21 (2): 118-29. doi:10.1016/j.jretconser.2013.07.002.

Özer, A., M. T. Argan, and M. Argan. 2013. The effect of mobile service quality dimensions on customer satisfaction. Procedia-Social and Behavioral Sciences 99: 428-38.

Pan, Y., and G. M. Zinkhan. 2006. Exploring the impact of online privacy disclosures on consumer trust. Joumal of Retailing 82: 331-38. doi:10.1016/j.jretai.2006.08.006.

Parasuraman, A. 2000. Technology readiness index (TRI): A multiple-item scale to measure readiness to embrace new technologies. Journal of Service Research. doi:10.1177/109467050024001.

Parasuraman, A., V. A. Zeithaml, and A. Malhotra. 2005. E-S-QUAL a multiple-item scale for assessing electronic service quality. Journal of Service Research 7 (3): 213-33. http://jsr.sagepub.com/content/ $7 / 3 / 213$.short.

Parasuraman, A., V. Zeithaml, and L. Berry. 1988. SERVQUAL: A multiple-item scale for measuring consumer perceptions of service quality. Journal of Retailing 64: 12-40.

Santos, J. 2003. E-service quality: A mjodel of virtual service quality dimensions. Managing Service Quality. doi:10.1108/09604520310476490.

Schumann, J. H., N. V. Wünderlich, and F. Wangenheim. 2012. Technology mediation in service delivery: A new typology and an agenda for managers and academics. Technovation 32: 133-43. doi:10.1016/ j.technovation.2011.10.002.

Sekaran, U., and R. Bougie. 2010. Research Methods for Business: A Skill Building Approach (5 ${ }^{\mathrm{TH}}$ ed.). John Wiley \& Sons. http:/ / books.google.lk/books?id=a__YI3TJQuAC.

Shamdasani, P., A. Mukherjee, and N. Malhotra. 2008. Antecedents and consequences of service quality in consumer evaluation of self-service internet technologies. The Service Industries Journal 28 (1): 117 38. doi:10.1080/02642060701725669.

Thalgodapitiya, R., and A. Bhoumik. 2012. The Sri Lankan Banking Sector. Special Report.

Van Riel, A., J. Semeijn, and W. Janssen. 2003. E-service quality expectations: A case study. Total Quality Management and Business Excellence. doi:10.1080/1478336032000047255. 
Venkatesh, V. 2000. Determinants of perceived ease of use: Integrating control, intrinsic motivation, and emotion into the technology acceptance model. Information Systems Research 11:342-65. doi:10.1287/ isre.11.4.342.11872.

Venkatesh, V., C. Speier, and M. G. Morris. 2002. User acceptance enablers in individual decision making about technology: Toward an integrated model. Decision sciences 33: 297-316. doi:10.1111/j.15405915.2002.tb01646.x.

Verhoef, P. C., K. N. Lemon, A. Parasuraman, A. Roggeveen, M. Tsiros, and L. A. Schlesinger. 2009. Customer experience creation: Determinants, dynamics and management strategies. Journal of Retailing 85: 31-41. doi:10.1016/j.jretai.2008.11.001.

Wang, M. C-H. 2012. Determinants and consequences of consumer satisfaction with self-service technology in a retail setting. Managing Service Quality.

Weijters, B., N. Schillewaert, D. Rangarajan, and T. Falk. 2005. Customers' usage of self service technology in a retail setting. Vlerick Leuven Gent Working Paper Series 2005/19: 1-37. http:// public.vlerick.com/publications/0e522f07-6aa9-e011-8a89-005056a635ed.pdf.

Weijters, B., D. Rangarajan, T. Falk, and N. Schillewaert. 2007. Determinants and outcomes of customers' use of self-service technology in a retail setting. Journal of Service Research. doi:10.1177/ 1094670507302990.

Yang, Z., M. Jun, and R. T. Peterson. 2004. Measuring customer perceived online service quality: Scale development and managerial implications. International Journal of Operations and Production Management 24 (11): 1149-74.

Yen, H. R. 2005. An attribute-based model of quality satisfaction for internet self-service technology. The Service Industries Journal 25 (5): 641-59. doi:10.1080/02642060500100833.

Zeithaml, V. A., A. Parasuraman, and A. Malhotra. 2002. An Empirical Examination of the Service QualityValue-Loyalty Chain in an Electronic Channel. NC.

Zhu, Z., C. Nakata, K. Sivakumar, and D. Grewal. 2013. Fix it or leave it? Customer recovery from selfservice technology failures. Journal of Retailing 89:15-29. doi:10.1016/j.jretai.2012.10.004. 